\title{
Arginine-, hypoxanthine-, uracil-requiring isolates of Neisseria gonorrhoeae are a clonal lineage within a non-clonal population
}

\author{
Thorsten S. Gutjahr, ${ }^{1}+$ Maria O'Rourke, ${ }^{1} \ddagger$ Catherine A. Ison ${ }^{2}$ \\ and Brian G. Spratt ${ }^{1}$ \\ Author for correspondence: Brian G. Spratt. Tel: +44 1273678 309. Fax: +44 1273678433. \\ e-mail: b.g.spratt@sussex.ac.uk
}

1 Molecular Microbiology Group, School of Biological Sciences, University of Sussex, Brighton BN1 9QG, UK

2 Department of Medical Microbiology, WrightFleming Institute, St Mary's Hospital Medical School, London W2 1PG, UK
Multilocus enzyme electrophoresis has shown that a collection of 101 arginine-, hypoxanthine-, uracil-requiring (AHU) ) isolates of Neisseria gonorrhoeae, recovered over a 39 year period from the UK and Denmark, were of a single electrophoretic type ( $91 \%$ of strains), or differed from the predominant electrophoretic type at only a single locus. The striking uniformity of the AHUisolates, and the correlation between auxotype, serovar and overall genetic background, contrasts with previous studies of gonococcal populations (that included very few AHU- strains), and a small sample of non-AHU- isolates studied here, which demonstrated a non-clonal population structure and a lack of association between auxotype, serovar and genetic background. There was no marked difference in the ability of AHU- isolates to be transformed with their own DNA, or with DNA from gonococci of other auxotypes, and the relative genetic stability of AHU- isolates does not appear to be due to a defect in their ability to be transformed. An alternative possibility is that AHUgonococci recombine with other lineages, but that the resulting recombinants are not maintained in the population. This would occur, for example, if AHUgonococci competed poorly in mixed infections, within which effective recombination between lineages occurs, and are usually only transmitted from individuals who are singly infected with an AHU- strain. The association between AHU- gonococci and asymptomatic infections may lead to an increased rate of transmission of these strains which under this scenario would be needed to prevent them from being lost from the population.

Keywords: genetic transformation, multilocus enzyme electrophoresis, population structure, recombination, gonorrhoea

\section{INTRODUCTION}

Neisseria gonorrhoeae populations have been shown to be non-clonal as alleles in the population do not depart significantly from linkage equilibrium (O'Rourke \& Stevens, 1993; Maynard Smith et al., 1993; Vázquez et al., 1993; O'Rourke \& Spratt, 1994). This implies that recombination between genetically distinct gonococcal

\footnotetext{
† Present address: Boehringer Mannheim GmbH, R \& D Biotechnology, Nonnenwald 2, D-82377 Penzberg, Germany.

$\ddagger$ Present address: Immuno AG, Biomedical Research Centre, Uferstrasse 15, A-2304 Orth, Austria.

Abbreviations: $\mathrm{AHU}^{-}$, arginine-, hypoxanthine- and uracil-requiring; $\mathrm{ET}$, electrophoretic type; MLEE, multilocus enzyme electrophoresis; UPGMA, unweighted-pair group method using average linkages.
}

lineages is frequent, and that mixed infections must be relatively common, as might be expected, particularly within the sexually active subpopulations (superspreaders or core groups) that are believed to sustain gonorrhoea within the community (Anderson \& May, 1991).

Recombination in bacteria is different from that in eukaryotes, as it involves the localized replacements of small chromosomal segments, typically of hundreds of base pairs to a few kilobases, with those from neighbouring isolates (Maynard Smith et al., 1991). In highly clonal populations, diversification via recombinational replacements is believed to be minor, compared to the diversification that occurs through mutation, and the population exists as independent lineages (clones) 
(Selander et al., 1990). In N. gonorrhoeae, localized recombinational replacements are believed to occur frequently, compared to mutation (Maynard Smith, 1994), resulting in the rapid diversification of bacterial lineages with time, as the originally homogeneous chromosomes within the members of a newly emerged lineage are increasingly pocked with recombinational replacements (Spratt et al., 1995). Eventually, the diversification of the lineage will be so great that its members can no longer be recognized.

The clones in highly clonal populations may persist almost unchanged for many decades as evolutionary change is mainly through the gradual introduction of diversity by mutational processes (Selander \& Musser, 1990). These stable clones are not expected within a non-clonal population and the gonococci isolated in this decade should be different from those in the next. However, even in non-clonal populations, lineages may be recognizable over time periods that are significant in human terms (months or years), although extremely short on evolutionary time scales (transient clones). There are many reports of gonococci with similar phenotypic properties that have been loosely described as clones (Sarafian \& Knapp, 1989). In many cases the description of these isolates as clones is probably not justified, and is due to the use of typing techniques that are not sufficiently discriminatory to distinguish the large number of genotypes expected in a non-clonal population (for example reliance only on identity of auxotype, based on nutritional requirements, and serovar, based on antigenic variation within the gonococcal porin, PI). However, there are examples where a strong case for relatively long-lived gonococcal clones can be made.

The arginine-, hypoxanthine-, uracil-requiring $\left(\mathrm{AHU}^{-}\right)$ gonococci provide the best candidates for a relatively long-lived clone of gonococci (Knapp \& Holmes, 1975; Mulks \& Knapp, 1987; Martin \& Mulks, 1992). These isolates are almost invariably serovar IA-2, are unusually susceptible to antibiotics, and are resistant to the bactericidal action of normal human serum (Schoolnik et al., 1976; Bohnoff et al., 1986; Morello \& Bohnoff, 1989). In addition, they produce type I immunoglobulin A1 protease (Mulks \& Knapp, 1987) and Dam methylase (Kolodkin et al., 1982), both of which are uncommon among gonococci of other auxotypes, and have a molecular lesion in the arginine biosynthetic pathway that is distinct from that in arginine-requiring non$\mathrm{AHU}^{-}$strains (Martin \& Mulks, 1992).

In this paper we examine $\mathrm{AHU}^{-}$strains of $N$. gonorrboeae recovered over a 39 year period and show that they fulfil the criteria of a relatively long-lived clone within a basically non-clonal population.

\section{METHODS}

Bacterial strains. Seventy two $\mathrm{AHU}^{-}$isolates of $N$. gonorrhoeae were recovered from patients attending the sexually transmitted disease (STD) clinic at St Mary's Hospital between 1986 and 1994. A further $29 \mathrm{AHU}^{-}$isolates were recovered in Denmark between 1956 and 1982 and were kindly supplied by Dr Inga Lind. In addition, 28 control gonococcal isolates, representing a range of auxotypes (but no $\mathrm{AHU}^{-}$strains), were obtained from patients attending the STD clinic at St Mary's in 1990. Three gonococcal strains commonly used in the laboratory, FA19, MS11 and FA1090, were also examined. Gonococci were grown on GC agar (Difco) supplemented with $1 \%$ IsoVitaleX (Becton Dickinson), or in GC broth supplemented with $1 \%$ IsoVitaleX.

Auxotyping. Auxotyping and determination of serovar were carried out as described by Woodford et al. (1989). Gonococci were tested for requirements for proline $\left(\mathrm{P}^{-}\right)$, arginine $\left(\mathrm{A}^{-}\right)$, hypoxanthine $\left(\mathrm{H}^{-}\right)$and uracil $\left(\mathrm{U}^{-}\right)$, and for combinations of these requirements. Isolates with no requirements for these nutrients were classified as prototrophic (NR).

Multilocus enzyme electrophoresis (MLEE). Preparation of gonococcal lysates, starch gel electrophoresis, and staining of enzymes were carried out as described previously (O'Rourke \& Stevens, 1993). Enzymes assayed included glutamate dehydrogenase (GD2), isocitrate dehydrogenase (IDH), glutamic-oxaloacetic transaminase (GOT), glucose-6-phosphate dehydrogenase (G6P), malic enzyme (MAE), alkaline phosphatase (ALP), adenylate kinase (ADK), leucylalanine peptidase (LAP), phenylalanyl-leucine peptidase (PLP) and leucylglycyl-glycine peptidase (LGP). Two additional enzymes, diaphorase (DIA) and 6-phosphogluconate (6PG), were assayed in the $\mathrm{AHU}^{-}$isolates. Distinctive mobility variants of each enzyme were numbered in order of decreasing rate of anodal migration and were equated with alleles of the corresponding structural genes. Isolates that appeared to have different mobility variants of an enzyme were re-run in adjacent tracks, together with reference isolates for each variant, to confirm the presence of distinct alleles. Each isolate was characterized by its combination of alleles at the ten (or twelve) enzyme loci. Distinctive combinations of alleles, corresponding to unique multilocus genotypes, were designated as electrophoretic types (ETs). A dendrogram was constructed from the matrix of pairwise differences between the electrophoretic profiles of the isolates using the unweighted-pair group method using average linkages (UPGMA). The diversity at each locus $(b)$ was calculated as $h=1-\Sigma x_{i}^{2}[n /(n-1)]$

where $x_{i}$ is the frequency of the $i^{\text {th }}$ allele and $n$ the number of isolates. The mean genetic diversity is the mean of the values of $b$ over all loci.

Analysis of linkage disequilibrium. A statistical test, the index of association $\left(I_{\mathrm{A}}\right)$, was performed to estimate the extent of linkage disequilibrium from the MLEE data (Maynard Smith et al., 1993). $I_{\mathrm{A}}$ measures the ratio of the variance in allelic mismatches observed for the data set, $V_{0}$, to the variance expected in a corresponding population at linkage equilibrium, $V_{\mathrm{e}}$. The value of $I_{\mathrm{A}}$ is equal to zero for a population in linkage equilibrium, and differs significantly from zero if there is significant association between alleles. An estimate of the statistical significance of the $I_{\mathrm{A}}$ value is made by calculating $V_{\mathrm{o}}$ from 100 random data sets. In each random set, the numbers of each allele, at each locus, were the same as in the real data, but the alleles were assigned randomly to isolates. If the data are in strong linkage disequilibrium (i.e. $P<0.01$ ), then none of the values of $V_{0}$ obtained from the random data sets should exceed that obtained with the real data.

Genetic transformation. N. gonorrboeae is naturally transformable, and competence is constitutively expressed, but 
requires piliated bacteria. Piliated $\mathrm{Rif}^{\mathrm{S}}$ bacteria are mixed with chromosomal DNA from a $\mathrm{Rif}^{\mathrm{R}}$ isolate and, after allowing time for DNA entry, homologous recombination and expression of rifampicin resistance, the bacteria are plated on agar containing rifampicin to select $\mathrm{Rif}^{\mathrm{R}}$ transformants. Controls to which chromosomal DNA was not added were used in all experiments. Transformation was carried out as described by Brannigan et al. (1990). A piliated colony of each gonococcal isolate was streaked across GC agar base supplemented with IsoVitaleX and, after incubation at $37^{\circ} \mathrm{C}$ in a $5 \%$ (v/v) $\mathrm{CO}_{2}$ atmosphere for $16 \mathrm{~h}$, the bacteria were resuspended to a cell density of approximately $5 \times 10^{7}$ bacteria $\mathrm{ml}^{-1}$ in GC broth supplemented with IsoVitaleX containing $5 \mathrm{mM}$ sodium bicarbonate and $4 \mathrm{mM}$ magnesium sulphate. One hundred microlitres of bacteria was mixed with $5 \mu \mathrm{l}$ (approx. $3 \mu \mathrm{g}$ ) of chromosomal DNA from rifampicin-resistant $\left(\mathrm{Rif}^{\mathrm{R}}\right)$ -derivatives of the gonococcal isolates. After $30 \mathrm{~min}$ at $37^{\circ} \mathrm{C}$, they were diluted fivefold with the same medium and grown for a further $5 \mathrm{~h}$. Rif ${ }^{\mathrm{R}}$ transformants were selected on agar containing $100 \mu \mathrm{g}$ rifampicin $\mathrm{ml}^{-1}$. Total viable recipient bacteria were scored on agar lacking rifampicin. Rif ${ }^{\mathrm{R}}$ derivatives were isolated as spontaneous mutants arising on agar containing $20 \mu \mathrm{g}$ rifampicin $\mathrm{ml}^{-1}$ and, for each isolate, a single colony from the first selective agar plates was grown up and second-level spontaneous $\mathrm{Rif}^{\mathrm{R}}$ mutants were isolated that grew on $100 \mu \mathrm{g}$ rifampicin $\mathrm{ml}^{-1}$.

\section{RESULTS}

\section{MLEE}

MLEE using 12 enzymes grouped the $101 \mathrm{AHU}^{-}$isolates into only seven ETs. Ninety-two (91\%) of the isolates were indistinguishable by MLEE, and this ET included gonococci recovered in both London and Denmark over a 39 year period. All of the other $\mathrm{AHU}^{-}$isolates differed from this predominant ET at only one of the 12 enzymes, or by a single null allele (Table 1). Five of the $\mathrm{AHU}^{-}$ isolates also required proline $\left(\mathrm{PAHU}^{-}\right)$, but $\mathrm{MLEE}$ using 12 enzymes did not distinguish these isolates from the $\mathrm{AHU}^{-}$isolates; all of them were members of the predominant ET.
A control sample of 31 non- $\mathrm{AHU}^{-}$gonococci were grouped into 15 multilocus genotypes using a subset of ten enzymes, among which eight ETs were represented by single isolates (Table 2). A dendrogram was constructed, using the ten enzymes assayed in both the $\mathrm{AHU}^{-}$and control isolates, and ETs were numbered in consecutive order according to their positions in the dendrogram (Fig. 1). Since recombination is extensive within gonococcal populations, the dendrogram does not depict phylogenetic relationships between isolates, but it is evident that the $\mathrm{AHU}^{-}$isolates comprised a distinct cluster of related ETs. One of the control isolates had the same ET as the majority of the $\mathrm{AHU}^{-}$ isolates (ET-4), but otherwise there was no overlap between the ETs of the $\mathrm{AHU}^{-}$isolates and the control isolates (Table 2). A single control isolate (the prototrophic strain 1440; ET-3) clustered with the $\mathrm{AHU}^{-}$ isolates, but this isolate, and the control isolate within ET-4, may not be closely related to the $\mathrm{AHU}^{-}$isolates since, given the observed allele frequencies and random assortment of alleles, 1.02 and 0.34 isolates of ET-4 and ET-3 would be expected to occur by chance among the 31 control isolates.

Five of the ten enzymes assayed for all isolates were polymorphic among the 31 control isolates, and the mean genetic diversity was $0 \cdot 17$, which was considerably less than the values reported previously from more comprehensive MLEE studies (O'Rourke \& Stevens, 1993; Vázquez et al., 1993). In the collection of 101 $\mathrm{AHU}^{-}$isolates, three of these ten enzymes were polymorphic and the mean genetic diversity was 0.01 (the two additional enzymes assayed in the $\mathrm{AHU}^{-}$isolates were monomorphic, excepting a single isolate that had a distinct allele of $6 \mathrm{PG}$ ).

The index of association $\left(I_{\mathrm{A}}\right)$ was used to estimate the extent of linkage disequilibrium between the alleles in the gonococcal populations (Maynard Smith et al., 1993). The value of $I_{\mathrm{A}}$ is equal to zero for a population

Table 1. Electrophoretic profiles of AHU- gonococci

The full electrophoretic profile of ET-A is shown. The profiles of the other isolates were identical (-), except where shown. 0, no activity could be detected (null allele). Isolates differing from ET-A by only a null allele were designated A1 and A2. See Methods for abbreviations for the enzymes.

\begin{tabular}{|llllllllllllll|}
\hline \multirow{2}{*}{$\begin{array}{l}\text { No. of } \\
\text { isolates }\end{array}$} & ET & \multicolumn{10}{c|}{ Electrophoretic variants of: } \\
\cline { 2 - 15 } & & GD2 & IDH & GOT & G6P & DIA & ME & ADK & ALP & 6PG & PLP & LAP & LGP \\
\hline 82 & A & 3 & 2 & 1 & 2 & 1 & 1 & 2 & 3 & 2 & 2 & 2 & 2 \\
9 & A1 & - & - & - & - & - & - & - & - & 0 & - & - & - \\
1 & A2 & - & - & - & - & - & - & - & 0 & - & - & - & - \\
1 & B & - & - & 2 & - & - & - & - & - & - & - & - & - \\
2 & C & - & - & - & - & - & - & - & - & 1 & - & - & - \\
2 & D & - & - & - & - & - & - & - & 4 & - & - & - & - \\
2 & E & - & - & - & - & - & - & - & 5 & - & - & - & - \\
1 & F & - & 3 & - & - & - & - & - & - & - & - & - & - \\
1 & G & - & 4 & - & - & - & - & - & - & - & - & - & - \\
\hline
\end{tabular}


Table 2. Electrophoretic profiles of $\mathrm{AHU}^{-}$and control (non-AHU-) gonococci

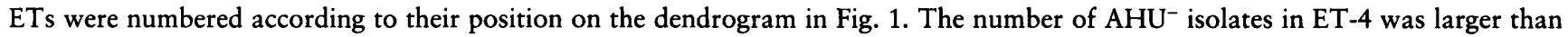
that in ET-A in Table 1 since two of the ET-4 isolates differed at one of the two additional enzymes used in Table 1 (6PG). See Methods for abbreviations for the enzymes.

\begin{tabular}{|c|c|c|c|c|c|c|c|c|c|c|c|c|}
\hline \multicolumn{2}{|c|}{ No. of isolates } & \multirow[t]{2}{*}{ ET } & \multicolumn{10}{|c|}{ Electrophoretic variants of: } \\
\hline $\mathrm{AHU}^{-}$ & Control & & GD2 & IDH & GOT & G6P & ME & ADK & ALP & PLP & LAP & LGP \\
\hline 2 & 0 & 1 & 3 & 2 & 1 & 2 & 1 & 2 & 4 & 2 & 2 & 2 \\
\hline 2 & 0 & 2 & 3 & 2 & 1 & 2 & 1 & 2 & 5 & 2 & 2 & 2 \\
\hline 0 & 1 & 3 & 3 & 2 & 1 & 2 & 1 & 2 & 2 & 2 & 2 & 2 \\
\hline 94 & 1 & 4 & 3 & 2 & 1 & 2 & 1 & 2 & 3 & 2 & 2 & 2 \\
\hline 1 & 0 & 5 & 3 & 2 & 2 & 2 & 1 & 2 & 3 & 2 & 2 & 2 \\
\hline 1 & 0 & 6 & 3 & 3 & 1 & 2 & 1 & 2 & 3 & 2 & 2 & 2 \\
\hline 1 & 0 & 7 & 3 & 4 & 1 & 2 & 1 & 2 & 3 & 2 & 2 & 2 \\
\hline 0 & 2 & 8 & 3 & 3 & 2 & 3 & 1 & 2 & 3 & 2 & 2 & 2 \\
\hline 0 & 2 & 9 & 3 & 2 & 2 & 3 & 1 & 2 & 3 & 2 & 2 & 2 \\
\hline 0 & 3 & 10 & 3 & 2 & 1 & 3 & 1 & 2 & 2 & 2 & 2 & 2 \\
\hline 0 & 8 & 11 & 3 & 2 & 1 & 3 & 1 & 2 & 3 & 2 & 2 & 2 \\
\hline 0 & 1 & 12 & 2 & 2 & 1 & 3 & 1 & 2 & 3 & 2 & 2 & 2 \\
\hline 0 & 1 & 13 & 4 & 2 & 1 & 3 & 1 & 2 & 3 & 2 & 2 & 2 \\
\hline 0 & 1 & 14 & 5 & 2 & 1 & 3 & 1 & 2 & 3 & 2 & 2 & 2 \\
\hline 0 & 1 & 15 & 2 & 1 & 1 & 2 & 1 & 2 & 3 & 2 & 2 & 2 \\
\hline 0 & 1 & 16 & 4 & 2 & 1 & 2 & 1 & 2 & 2 & 2 & 2 & 2 \\
\hline 0 & 1 & 17 & 4 & 3 & 1 & 3 & 1 & 2 & 2 & 2 & 2 & 2 \\
\hline 0 & 1 & 18 & 1 & 1 & 1 & 3 & 1 & 2 & 2 & 2 & 2 & 2 \\
\hline 0 & 2 & 19 & 1 & 3 & 1 & 3 & 1 & 2 & 3 & 2 & 2 & 2 \\
\hline 0 & 5 & 20 & 3 & 3 & 1 & 3 & 1 & 2 & 3 & 2 & 2 & 2 \\
\hline
\end{tabular}

in linkage equilibrium, and differs significantly from zero if there is significant association between alleles. For the control group of isolates the $I_{\mathrm{A}}$ value was $0 \cdot 12$. This value was not significantly different from zero $\left\langle a V_{0}\right.$ greater than that observed in the real data set was obtained in 23 of 100 random data sets; see Methods), indicating that there was no significant linkage disequilibrium between the alleles in the control gonococci. Although there is not enough variation within the $\mathrm{AHU}^{-}$ isolates to calculate an $I_{\mathrm{A}}$ value, there was obvious linkage disequilibrium between alleles as $>90 \%$ of the isolates had the identical ET, and each of the other strains differed from the predominant ET at only a single locus.

\section{Differences in transformation efficiency in $\mathrm{AHU}^{-}$and non-AHU- strains}

Initially sixteen isolates were screened in transformation experiments: these comprised eight $\mathrm{AHU}^{-}$isolates, four prototrophic isolates, one proline-, arginine- and uracilrequiring isolate, one arginine- and uracil-requiring isolate, and two proline-requiring isolates. Each of the isolates was used as a recipient with donor chromosomal DNA from FA19-Rif ${ }^{\mathrm{R}}$. Eight of the isolates failed to be transformed to rifampicin resistance, presumably because they had lost their pili on subculture or storage. Four of these isolates were $\mathrm{AHU}^{-}$and four were non$\mathrm{AHU}^{-}$. The remaining eight isolates were used for further transformation experiments and Rif $^{\mathrm{R}}$-derivatives of each were selected as described in Methods. Each isolate was transformed to rifampicin resistance with its own DNA (using DNA from the Rif ${ }^{\mathbf{R}}$-derivatives), and with DNA from the $\mathrm{AHU}^{-}$isolate $2168-\mathrm{Rif}^{\mathrm{R}}$, and from FA19-Rif ${ }^{\mathrm{R}}$ (non-requiring) (Table 3).

There was no apparent barrier to transformation among $\mathrm{AHU}^{-}$isolates, which were transformed at approximately the same frequency with $\mathrm{AHU}^{-} \mathrm{DNA}$, as with DNA from the prototrophic strain FA19. Similarly each of the three prototrophic isolates, and the prolinerequiring isolates, were transformed at approximately the same frequency with DNA from $\mathrm{AHU}^{-}$isolates or isolates of other auxotypes. The transformation experiments included several recipient isolates, but included donor DNA from only two isolates, FA19 and 2168 (and isogenic DNA). Since individual isolates may differ in restriction-modification systems, or in the frequency and distribution of uptake sequences, it is possible that different results might have been obtained using alternative donor isolates. Consequently, the transformation experiments were repeated using donor DNA from $\mathrm{Rif}^{\mathrm{R}}$-derivatives of two further $\mathrm{AHU}^{-}$isolates (1511 and M186) and two further non-AHU ${ }^{-}$isolates (1474 and 1569). The results from the transformation experiments using DNA from these donors also showed no significant reduction in the ability of $\mathrm{AHU}^{-}$isolates to be transformed with either their own DNA or DNA from non- 


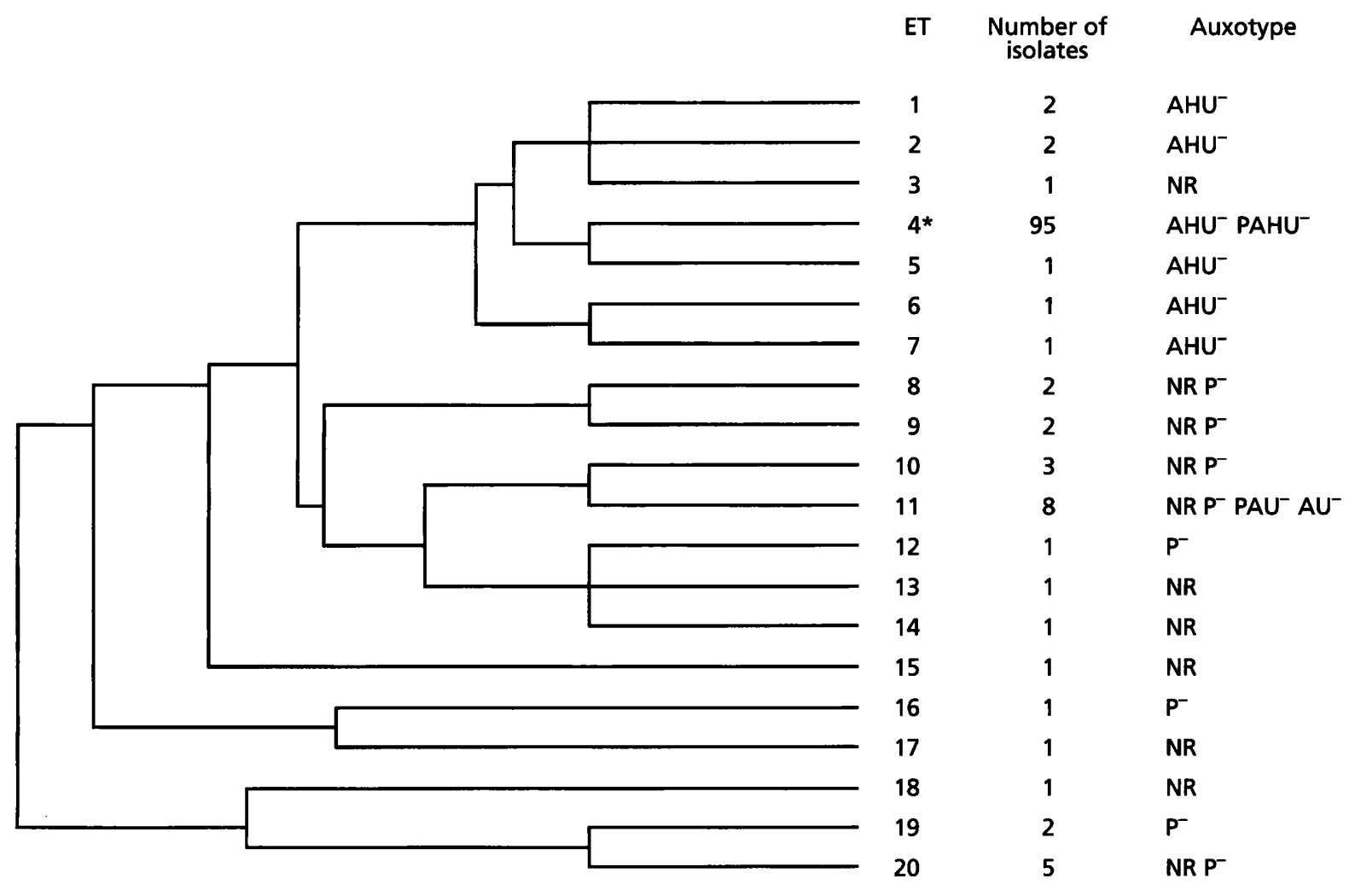

Fig. 1. Dendrogram constructed from the electrophoretic profiles of the $A H U^{-}$and control strains. The dendrogram was constructed from a matrix of the pairwise differences between the electrophoretic profiles of the $101 \mathrm{AHU}^{-}$, and the 31 control isolates, using UPGMA. In this basically non-clonal population the dendrogram does not reflect the genetic relationships between the isolates. Randomizing the input order of the ETs usually resulted in a clustering of the AHU strains and ET-3, but resulted in a different clustering of the control isolates. The number of isolates within each of the ETs, and the auxotypes of isolates within each ET, are shown. *ET-4 also includes one control strain.

Table 3. Transformation frequencies of $\mathrm{AHU}^{-}$and control recipients

\begin{tabular}{|c|c|c|c|c|}
\hline \multirow[t]{2}{*}{ Recipient strain } & \multirow[t]{2}{*}{ Auxotype* } & \multicolumn{3}{|c|}{$\begin{array}{l}\text { Transformation frequencies using DNA from } \text { Rif }^{\mathrm{R}}- \\
\text { derivatives of strains: }\end{array}$} \\
\hline & & FA19 (NR) & $2168\left(\mathrm{AHU}^{-}\right)$ & Recipient $\dagger$ \\
\hline 2168 & $\mathrm{AHU}^{-}$ & $3.1 \times 10^{-4}$ & $6.8 \times 10^{-4}$ & $6.8 \times 10^{-4}$ \\
\hline M186 & $\mathrm{AHU}^{-}$ & $2 \cdot 1 \times 10^{-5}$ & $2 \cdot 3 \times 10^{-5}$ & $3.6 \times 10^{-5}$ \\
\hline 1511 & $\mathrm{AHU}^{-}$ & $5 \cdot 3 \times 10^{-5}$ & $6.6 \times 10^{-5}$ & $1.6 \times 10^{-5}$ \\
\hline FA1090 & $\mathbf{P}^{-}$ & $5 \cdot 2 \times 10^{-4}$ & $6.6 \times 10^{-4}$ & $3.7 \times 10^{-4}$ \\
\hline 1569 & $\mathrm{P}^{-}$ & $3.4 \times 10^{-4}$ & $1.8 \times 10^{-4}$ & $8.2 \times 10^{-3}$ \\
\hline FA19 & NR & $1.0 \times 10^{-3}$ & $8.6 \times 10^{-4}$ & $1.0 \times 10^{-3}$ \\
\hline MS11 & NR & $6 \cdot 1 \times 10^{-4}$ & $2.5 \times 10^{-4}$ & $1.5 \times 10^{-4}$ \\
\hline 1474 & NR & $3 \cdot 3 \times 10^{-4}$ & $2 \cdot 2 \times 10^{-4}$ & $3.9 \times 10^{-4}$ \\
\hline
\end{tabular}

" $\mathrm{AHU}^{-}$, arginine-, hypoxanthine- and uracil-requiring; $\mathrm{NR}$, no requirement for proline, arginine, hypoxanthine or uracil; $\mathrm{P}^{-}$, proline-requiring.

† Chromosomal DNA from Rif $^{R}$-derivative of the recipient strain. The transformation frequency is the fraction of the viable recipient bacteria that are $\mathrm{Rif}^{\mathrm{R}}$. The frequency of spontaneous mutants resistant to $100 \mu \mathrm{g}$ rifampicin $\mathrm{ml}^{-1}$ was $<1 \times 10^{-8}$. 
$\mathrm{AHU}^{-}$isolates, compared to non- $\mathrm{AHU}^{-}$isolates (data not shown).

\section{DISCUSSION}

The uniformity of $\mathrm{AHU}^{-}$isolates contrasts with previous studies of gonococcal populations, which contained very few (O'Rourke \& Stevens, 1993) or no (Vázquez et al., 1993) $\mathrm{AHU}^{-}$strains, and which showed no association between ET and auxotype or serotype (De la Fuente \& Vázquez, 1994). The small sample of gonococci used as a control group of non- $\mathrm{AHU}^{-}$strains also showed no clear association between ET and auxotype, as five of the six ETs that contained more than one isolate included strains of different auxotypes. The alleles in the non- $\mathrm{AHU}^{-}$isolates did not depart significantly from linkage equilibrium, as found previously for the larger gonococcal populations studied by O'Rourke \& Stevens (1993) and by Vázquez et al. (1993). There was almost total linkage disequilibrium between alleles in the $\mathrm{AHU}^{-}$isolates, as almost all of these strains had identical alleles at each of the 12 loci examined, and each of the other strains differed from the predominant ET at only a single locus. It is difficult to escape the conclusion that the $\mathrm{AHU}^{-}$strains are members of a clone within a non-clonal population. A greatly reduced level of genetic variation in $\mathrm{AHU}^{-}$ isolates, compared to the total gonococcal population, has also been reported (Musser et al., 1985).

There are other reasons for believing that $\mathrm{AHU}^{-}$isolates are genetically more uniform than gonococci of other auxotypes. The opa genes, which are normally highly variable among gonococcal populations, appear to be relatively uniform among $\mathrm{AHU}^{-}$isolates (Brooks et al., 1991; O'Rourke et al., 1995). Similarly, Li \& Dillon (1995) have shown recently that $\mathrm{AHU}^{-}$isolates are relatively uniform by ribotyping and pulsed-field gel electrophoresis, although it is not possible from the data presented in their study to relate the observed level of variation to that in the whole gonococcal population. Furthermore, as outlined in the introduction, $\mathrm{AHU}^{-}$ isolates share a number of common genotypic and phenotypic properties.

The genetic stability of $\mathrm{AHU}^{-}$isolates over at least 39 years suggests that they diversify more slowly than other gonococci. Diversification of gonococci is believed to occur rapidly as a result of frequent recombination (Spratt et al., 1995; O'Rourke et al., 1995), and the most likely explanation for the uniformity of the $\mathrm{AHU}^{-}$ strains is that recombinational replacements from genetically distinct lineages are rare in these strains for some reason. The fact that $\mathrm{AHU}^{-}$strains have not acquired plasmids that encode $\beta$-lactamase (Ison \& Easmon, 1991), although these plasmids are widely distributed in other gonococci, also suggests that $\mathrm{AHU}^{-}$ isolates have restricted genetic exchange with other gonococci.

Restricted recombination can be explained in two main ways. Firstly, a lineage in the population may lose, or reduce, its ability to exchange chromosomal genes with other lineages. In the case of gonococci, this might reflect a defect in genes involved in natural transformation or the presence of particularly potent restriction-modification systems. Variation within this 'asexual' lineage would then accumulate much more slowly than in the whole population as it would depend entirely, or predominantly, on mutation rather than recombination. However, the clonal nature of the $\mathrm{AHU}^{-}$ isolates does not appear to be due to a loss of their ability to be transformed with chromosomal DNA from other gonococci. We could find no significant difference between the frequency of transformation of $\mathrm{AHU}^{-}$ strains compared to non- $\mathrm{AHU}^{-}$strains. Furthermore, $\mathrm{AHU}^{-}$strains were transformed at similar frequencies by their own chromosomal DNA, or DNA from other gonococci. We therefore believe that there is no major defect in the ability of $\mathrm{AHU}^{-}$strains to be transformed, although our experiments would not be able to detect a small difference $(<10$-fold) in transformability.

Alternatively, a reduction in the frequency of recombination within a lineage of a non-clonal population may be related to reduced contact with other lineages, i.e. to differences in ecology or population biology, rather to any defect in the process of transformation. The rapid diversification of lineages by recombination that occurs within non-clonal populations requires that genetically distinct individuals meet each other. Reduced contact between different lineages has been proposed as a possible reason for the strongly clonal nature of serogroup A meningococci (Achtman, 1994), compared to the basically non-clonal serogroup $\mathrm{B} / \mathrm{C}$ meningococci (Spratt et al., 1995). Serogroup A isolates cause epidemics of meningitis (Achtman, 1994) and rapid transmission between individuals, less frequent carriage, and shorter duration of carriage, would inevitably reduce the extent to which serogroup A lineages meet meningococci of other lineages, and may allow serogroup A meningococcal lineages to avoid the disruptive effect of recombination, and thus to persist longer than those of serogroup B/C meningococci (Maiden \& Feavers, 1995; Spratt et al., 1995).

This type of argument is less easy to apply to gonococci, as it requires $\mathrm{AHU}^{-}$isolates to be less commonly encountered in mixed infections than other gonococci. There appears to be no evidence that $\mathrm{AHU}^{-}$gonococci occupy a different niche from other gonococci (except that they are not recovered from the rectum), although this possibility should perhaps not be totally discounted as we do not know why polymorphisms in nutritional requirements (auxotypes) are maintained in the gonococcal population.

Another possibility relates to the fact that $\mathrm{AHU}^{-}$strains grow slowly in vitro compared to other gonococci (Morello et al., 1976; Crawford et al., 1977; Eisenstein et al., 1977). If they also grow slowly in vivo, this could influence the rate at which diversification of these strains occurs by recombination, as they would be rapidly 
overgrown by the other gonococcal isolate(s) in mixed infections. Transmission of $\mathrm{AHU}^{-}$strains to new hosts would then rarely occur from the mixed infections, where effective recombination occurs, and most of the transmissions of $\mathrm{AHU}^{-}$strains to new hosts would be from individuals who are singly infected with an $\mathrm{AHU}^{-}$ strain. This explanation might also explain the rarity of antibiotic-resistance genes in $\mathrm{AHU}^{-}$strains (Catlin \& Reyn, 1982; Knapp et al., 1985 ; Bohnhoff et al., 1986) as, in most cases, these must be acquired from antibioticresistant strains in mixed infections. However, if this were so, $\mathrm{AHU}^{-}$strains would probably be lost from the population, unless there were other factors that increased their chance of transmission to new hosts. The ability of $\mathrm{AHU}^{-}$strains to cause asymptomatic infections (Crawford et al., 1977; Cannon et al., 1983; Brunham et al., 1985; Sarafian \& Knapp, 1989; Ross et al., 1994) is one factor that would increase their transmission. Another factor that could increase transmission is the poor growth of $\mathrm{AHU}^{-}$strains on primary isolation, and their hypersusceptibility to vancomycin, which may result in failure to grow on the standard isolation media that contain vancomycin (Sarafian \& Knapp, 1989; Mirrett et al., 1981; Koelbl \& Catlin, 1986). Failure to detect gonococci may result in failure to prescribe antibiotics, leading to continued infection and increased transmission of these strains to new hosts.

In conclusion, our results show that a relatively longlived clone exists within the basically non-clonal gonococcal population. Other examples of this phenomenon may occur. For example, proline-, citrulline, uracilrequiring strains also appear to be relatively uniform, and were proposed to be a clone by $\mathrm{Ng} \&$ Dillon (1993), although more recent studies using pulsed-field gel electrophoresis from the same laboratory have argued that this may not be the case $(\mathrm{Ng}$ et al., 1995).

\section{ACKNOWLEDGEMENTS}

We are grateful to Inga Lind for providing gonococcal isolates. This work was supported by The Wellcome Trust. B.G.S. is a Wellcome Trust Principal Research Fellow.

\section{REFERENCES}

Achtman, M. (1994). Clonal spread of serogroup A meningococci: a paradigm for the analysis of microevolution in bacteria. Mol Microbiol 11, 15-22.

Anderson, R. M. \& May, R. M. (1991). Infectious Diseases in Humans. Oxford, UK: Oxford Scientific.

Bohnhoff, M., Morello, J. A. \& Lerner, S. A. (1986). Auxotypes, penicillin susceptibility, and serogroups of Neisseria gonorrboeae from disseminated and uncomplicated infections. J Infect Dis 154, 225-230.

Brannigan, J. A., Tirodimos, I. A., Zhang, Q.-Y., Dowson, C. G. \& Spratt, B. G. (1990). Insertion of an extra amino acid is the main cause of the low affinity of penicillin-binding protein 2 in penicillin-resistant strains of Neisseria gonorrhoeae. Mol Microbiol 4, 913-919.

Brooks, G. F., Olinger, L., Lammel, C. J., Bhat, K. S., Calvello, C. A., Palmer, M. L., Knapp, J. S. \& Stephens, R. S. (1991). Prevalence of gene sequences coding for hypervariable regions of Opa (protein II) in Neisseria gonorrhoeae. Mol Microbiol 5, 3063-3072.

Brunham, R. C., Plummer, F., Slaney, L., Rand, F. \& DeWitt, W. (1985). Correlation of auxotype and protein I type with expression of disease due to Neisseria gonorrhoeae. J Infect Dis 152, 339-343.

Cannon, J. G., Buchanan, T. M. \& Sparling, P. F. (1983). Confirmation of association of protein 1 serotype of Neisseria gonorrhoeae with ability to cause diseminated infection. Infect Immun 40, 816-819.

Catlin, B. W. \& Reyn, A. (1982). Neisseria gonorrboeae isolated from disseminated and localized infections in pre-penicillin era. Auxotypes and antibacterial drug resistances. $\mathrm{Br} J$ Vener Dis 58, 158-165.

Crawford, G., Knapp, J. S., Hale, J. \& Holmes, K. K. (1977). Asymptomatic gonorrhea in men caused by gonococci with unique nutritional requirements. Science 196, 1352-1353.

De la Fuente, L. \& Vázquez, J. A. (1994). Genetic structures of nonpenicillinase-producing Neisseria gonorrboeae strains in relation to auxotype and serovar class. $J$ Infect Dis 170, 696-700.

Eisenstein, B. I., Lee, T. J. \& Sparling, P. F. (1977). Penicillin and serum resistance are independent attributes of strains of Neisseria gonorrhoeae causing disseminated gonococcal infections. Infect Immun 15, 834-841.

Ison, C. A. \& Easmon, C. S. F. (1991). Epidemiology of penicillinresistant Neisseria gonorrhoeae. Genitourin Med 67, 307-311.

Knapp, J. S. \& Holmes, K. K. (1975). Disseminated gonococcal infections caused by Neisseria gonorrhoeae with unique growth requirements. J Infect Dis 132, 204-208.

Knapp, J. S., Mulks, M. H., Lind, I., Short, H. B. \& Clark, V. L. (1985). Evolution of gonococcal populations in Copenhagen, 1928-1979. In The Pathogenic Neisseriae, pp. 82-88. Edited by G. K. Schoolnik, G. F. Brooks, S. Falkow, C. E. Frasch, J. S. Knapp, J. A. McCutchan \& S. A. Morse. Washington, DC: American Society for Microbiology.

Koelbl, J. A. \& Catlin, B.W. (1986). Vancomycin hypersusceptibility in Neisseria gonorrboeae isolated from patients involves diverse mutations. Antimicrob Agents Chemother 29, $687-695$.

Kolodkin, A. B., Clark, V. L., Tenover, F. C. \& Young, F. E. (1982). High correlation of the presence of methyladenine in Neisseria gonorrhoeae DNA with the AHU auxotype. Infect Immun 36, $586-590$.

Li, H. \& Dillon, J.-A. R. (1995). Utility of ribotyping, restriction endonuclease analysis and pulsed-field gel electrophoresis to discriminate between isolates of Neisseria gonorrhoeae of serovar IA-2 which require arginine, hypoxanthine or uracil for growth. $J$ Med Microbiol 43, 208-215.

Maiden, M. C. J. \& Feavers, I. M. (1995). Population genetics and global epidemiology of the human pathogen Neisseria meningitidis. In The Population Genetics of Bacteria (SGM Symposium no. 52), pp. 269-293. Edited by S. Baumberg, J. P. W. Young, E. M. H. Wellington \& J. R. Saunders. Cambridge: Cambridge University Press.

Martin, P. R. \& Mulks, M. H. (1992). Molecular characterization of the arg J mutation in Neisseria gonorrhoeae strains with requirements for arginine, hypoxanthine, and uracil. Infect Immun 60, 970-975.

Maynard Smith, J. (1994). Estimating the minimum rate of genetic transformation in bacteria. J Evol Biol 7, 525-534.

Maynard Smith, J., Dowson, C. G. \& Spratt, B. G. (1991). Localized sex in bacteria. Nature 349, 29-31.

Maynard Smith, J., Smith, N. H., O'Rourke, M. \& Spratt, B. G. 
(1993). How clonal are bacteria? Proc Natl Acad Sci USA 90, $4384-4388$.

Mirrett, S., Reller, L. B. \& Knapp, J. S. (1981). Neisseria gonorrboeae strains inhibited by vancomycin in selective media and correlation with auxotype. J Clin Microbiol 14, 94-99.

Morello, J. A. \& Bohnhoff, M. (1989). Serovars and serum resistance of Neisseria gonorrhoeae from disseminated and uncomplicated infections. J Infect Dis 160, 1012-1017.

Morello, J. A., Lerner, S. A. \& Bohnhoff, M. (1976). Characteristics of atypical Neisseria gonorrhoeae from disseminated gonococcal infections. Infect Immun 13, 1510-1516.

Mulks, M. H. \& Knapp, J. S. (1987). Immunoglobulin A1 protease types of Neisseria gonorrboeae and their relationship to auxotype and serovar. Infect Immun 55, 931-936.

Musser, J. M., Short, H. B. \& Selander, R. K. (1985). Genetic heterogeneity within auxotypes of Neisseria gonorrboeae. Annual Meeting of the American Society for Microbiology, abstract D28. Washington, DC: American Society for Microbiology.

Ng, L. K. \& Dillon, J.-A. R. (1993). Typing by serovar, antibiogram, plasmid content, riboprobing, and isoenzyme typing to determine whether Neisseria gonorrhoeae isolates requiring proline, citrulline, and uracil for growth are clonal. J Clin Microbiol 31, 1555-1561.

Ng, L. K., Carballo, M. \& Dillon, J.-A. R. (1995). Differentiation of Neisseria gonorrboeae isolates requiring proline, citrulline, and uracil by plasmid content, serotyping, and pulsed-field gel electrophoresis. J Clin Microbiol 33, 1039-1041.

O'Rourke, M. \& Spratt, B. G. (1994). Further evidence for the nonclonal population structure of Neisseria gonorrhoeae: extensive genetic diversity within isolates of the same electrophoretic type. Microbiology 140, 1285-1290.

O'Rourke, M. \& Stevens, E. (1993). Genetic structure of Neisseria gonorrboeae populations: a non-clonal pathogen. J Gen Microbiol 139, 2603-2611.

O'Rourke, M., Ison, C. A., Renton, A. M. \& Spratt, B. G. (1995). Opa-typing - a high resolution tool for studying the epidemiology of gonorrhoea. Mol Microbiol 17, 865-875.
Ross, J. D. C., Wardropper, A., Sprott, M., Moyes, A. \& Young, H. (1994). Gonococcal infection in Edinburgh and Newcastleserovar prevalence in relation to clinical features and sexual orientation. Genitourin Med 70, 35-39.

Sarafian, S. K. \& Knapp, J. S. (1989). Molecular epidemiology of gonorrhoea. Clin Microbiol Rev 2, S49-S55.

Schoolnik, G. K., Buchanan, T. M. \& Holmes, K. K. (1976). Gonococci causing disseminated gonococcal infections are resistant to the bactericidal action of normal human serum. J Clin Invest 58, 1163-1173.

Selander, R. K. \& Musser, J. M. (1990). Population genetics of bacterial pathogenesis. In Molecular Basis of Bacterial Infections, pp. 11-36. Edited by B. H. Iglewski \& V. L. Clark. San Diego, CA: Academic Press.

Selander, R. K., Beltran, P., Smith, N. H., Helmuth, R., Rubin, F. A., Kopecko, D. J., Ferris, K., Tall, B. D., Cravioto, A. \& Musser, J. M. (1990). Evolutionary genetic relationships of clones of Salmonella serovars that cause human typhoid and other enteric fevers. Infect Immun 58, 2262-2275.

Spratt, B. G., Smith, N. H., Zhou, J., O'Rourke, M. \& Feil, E. (1995). The population genetics of the pathogenic Neisseria. In Population Genetics of Bacteria (SGM Symposium no. 52), pp. 143-160. Edited by S. Baumberg, J. P. W. Young, E. M. H. Wellington \& J. R. Saunders. Cambridge: Cambridge University Press.

Vázquez, J. A., De la Fuente, L., Berrón, S., O'Rourke, M., Smith, N. H., Zhou, J. \& Spratt, B. G. (1993). Ecological separation and genetic isolation of Neisseria gonorrhoeae and Neisseria meningitidis. Curr Biol 3, 567-572.

Woodford, N., Bindayna, K. M., Easmon, C. S. F. \& Ison, C. A. (1989). Associations between serotype and susceptibility to antibiotics of Neisseria gonorrboeae. Genitourin Med 65, 86-91.

Received 12 August 1996; revised 25 September 1996; accepted 4 October 1996. 